\title{
DEVELOPMENT OF A MOWER FOR GRASS HARVESTING
}

\author{
Atallah, M. M.*
}

\begin{abstract}
$\underline{\text { ABSTRACT }}$
The aim of this study is to development, construct and test a mower for small-scale in grass harvesting. The mower consisted of the main components including the frame, cutting mechanism, drive drum, gauge rollers, electrical motor, power transmission and handle. The results can be summarized as follows: the maximum machine productivity of 599.4 $\mathrm{m}^{2} / \mathrm{h}(0.143 \mathrm{fed} . / \mathrm{h})$ was obtained with forward speed of $2.16 \mathrm{~km} / \mathrm{h}$, cutting height of $2 \mathrm{~cm}$ and cutting speed of $6 \mathrm{~m} / \mathrm{s}$. Meanwhile, the minimum machine-productivity of $216.9 \mathrm{~m}^{2} / \mathrm{h}(0.052 \mathrm{fed} / \mathrm{h})$ was obtained with forward speed of $0.84 \mathrm{~km} / \mathrm{h}$, cutting height of $5 \mathrm{~cm}$ and cutting speed of $4.1 \mathrm{~m} / \mathrm{s}$. The maximum cutting-efficiency of $98.8 \%$ was obtained with forward speed of $0.84 \mathrm{~km} / \mathrm{h}$, cutting height of $2 \mathrm{~cm}$ and cutting speed of 6 $\mathrm{m} / \mathrm{s}$. The maximum power requirements of $0.70 \mathrm{~kW}$ was obtained with forward speed of $2.16 \mathrm{~km} / \mathrm{h}$, cutting height of $5 \mathrm{~cm}$ and cutting speed of 6 $\mathrm{m} / \mathrm{s}$. Meanwhile, the maximum specific energy of $11.27 \mathrm{~kW} . \mathrm{h} / \mathrm{fed}$. was obtained with forward speed of $0.84 \mathrm{~km} / \mathrm{h}$, cutting height of $5 \mathrm{~cm}$ and cutting speed of $6 \mathrm{~m} / \mathrm{s}$.

The experimental results revealed that the use of the developed grassmower maximized cutting efficiency and minimized energy. The operational cost and cost of production were 11.5 L.E./h and 193.3 L.E./fed. respectively, was obtained with forward speed of $0.84 \mathrm{~km} / \mathrm{h}$.
\end{abstract}

\section{INTRODUCTION}

ublic and special gardens play a vital role in the population life.
The green bed (grass) refines the atmosphere from the bad
particles of pollution in the air. Green bed is used widely as a playground for most games in different clubs. The grass had to be cut at such periods to be ready for using.

\footnotetext{
*Researcher at the Agricultural Engineering Research Institute (AEnRI), ARC Giza.
} 
This process is still operated depending on primitive methods using manual tools. So, grass cutting by means of up to date technology taking into consideration machine efficiency, durability, energy, and cost is an important question to be answered.

Many researches were carried out on the shearing mechanisms of mower and the design variables which affect the cutting energy. But data concerning grass mower and their performance were not available.

The grass mower is available in the various types, but these are very costly and unaffordable. It required a skilled person to operate. Hence, it was found necessary to have a grass mower which can be operated by electrical motor with minimum initial cost and can be operated by unskilled labor (Magar et al. 2010).

Chattopadhyay et al. (2010) evaluated four types of forage harvesting machines, namely flail mower, rotary mower, rotary disc mower and mechanical rake-cum-windrower for harvesting grasses (Cencrusciliaris) and their performances were compared with improved sickle (Gujarat Agro). The average effective field capacities were found to be $0.21,0.03$ and $0.285 \mathrm{ha} / \mathrm{h}$ for flail mower, rotary mower and rotary disc mower respectively and $133 \mathrm{man}-\mathrm{h} / \mathrm{ha}$ was required for harvesting the grasses by Gujarat Agro sickle. The overall cost of harvesting was found minimum (Rs. 26.00/t) and it was found maximum (Rs.36.00) for cutting the grass by Gujarat Agro sickle.

Magar et al. (2010) stated that the grass cutting machine is available in the various types like reel (cylinder) mower, rotary and mulching mower, hover mower, riding mower, professional mower etc. but these are very costly and unaffordable. It required a skilled person to operate.

Kemper et al. (2012) stated that disc mowers cutting principle is based upon using the inertia and bending forces of the grass blades. The established technology is reliable but others provide potential for reducing the power requirements. At the Institute of Mobile Machines and Commercial Vehicles an overlaying cut as an alternative cutting principle in a disc mower has to be proven. Therefore, a modified cutting unit is designed with two cutting discs. The aims of the project are to 
improve the cutting quality, to reduce the power requirements and to build up a simulation model of the process.

Piccarolo (2012) mentioned that professional lawns in parks and the like in Italy require special care and a scientifically based choice of grasses and machinery and emphasizes the close connection between mowing frequency and height, and that the choice of mower and type of cutting tool depends on the types of surface and the required mowing height.

Celik (2006) designed, fabricated, and test a push type cutter bar mower for use by small-scale enterprises in forage harvesting. Price, land condition, and enterprise size were considered as the main criteria for the design and development process. The cutter bar mower consisted of six main components including the cutting, transmission, power, handling, frame, and transporting units. A two-cycle engine that produced $1.47 \mathrm{~kW}$ at $7000 \mathrm{rpm}$ provided power for the cutting unit. Two skids were attached to the cutter bar unit, one on each side, to control cutting height. The total mass of the mower was $41 \mathrm{~kg}$. Performance tests of the mower resulted in an average $0.11 \mathrm{ha} / \mathrm{h}$ effective field capacity, $10.00 \mathrm{~L} / \mathrm{h}$ fuel consumption, 0.875 field efficiency, $2.24 \mathrm{t} / \mathrm{h}$ effective wet grass harvesting capacity, $4.43 \mathrm{~L} / \mathrm{t}$ wet grass specific fuel consumption, and 64 mm cutting height.

Kumhala et al. (2003) developed and tested two methods for the measurement of the mowing machine material feed rate (based on the conditioner power input measured by a torquemeter, and/or on the material change in momentum measured by a curved impact plate). The mowing machine (ZTR $216 \mathrm{H}$ ) used in the study was from the Czech Republic. A mixture of lucerne and grass was used in the measurements. The measurements carried out in the year 2001 proved that a very good linear relationship existed between the conditioner power input, output frequency of the apparatus measuring the impact force by means of the impact plate, and the material feed rate through the mowing machine. The calculated R-Squared values were approximately 0.95. Keepin (2003) mentioned that keeping mower blades really sharp can lead to a reduction in turf maintenance costs. Improving the quality of the cut 
helps to make the grass less susceptible to disease and reduces the need for water and chemicals.

Kumhala (1998) compared between 3 types of mowing machinery for meadow grass. The machines using a cutter bar mower with 2 drum mowers were investigated in 1996, and machines using a cutter bar mower and one drum mower were compared and evaluated in 1997. The capacity of work was higher for the cutter bar mower, and the rotary drum mowers always had higher energy consumption (about twice as much) in equal working conditions compared with the cutter bar mower.

Jagielski and Treder (1998) said that mowing grass in orchards is a time and energy consuming task. In Poland, mowing is carried out using rotary mowers that cut grass to a minimum height of $5 \mathrm{~cm}$, which causes fast regrowth and necessitates frequent mowing. Drum mowers are able to cut the grass lower, causing damage to nodes, periodical growth inhibitions and prolonged regrowth. Comparative tests proved the usability of drum mowers in orchards. Although both types of drum mower (KB-2 and KB-1.8) required more power than the rotary mower (RG-1.5), a reduced number of cuttings makes their use cheaper over the year.

The objectives of the present research are:

1- Development, constructing and testinga grass mower to improve its performance and minimize the operational cost.

2- Selecting the optimum conditions (forward speed, cutting speed and cutting height) for operating the developed grass-mower.

3- Evaluation of the developed machine from the economic point of view.

\section{MATERIALS AND METHODS \\ The developed grass mower : \\ The developed grass-mower was constructed in a local workshop and tested in public gardens in Cairo Governorate and Nadi El Said club in the golf course (in Giza Governorate). The views and photographs of developed grass-mower are shown in Figs 1 and 2. The overall dimensions: total length of $460 \mathrm{~mm}$, total width of $430 \mathrm{~mm}$, effective}




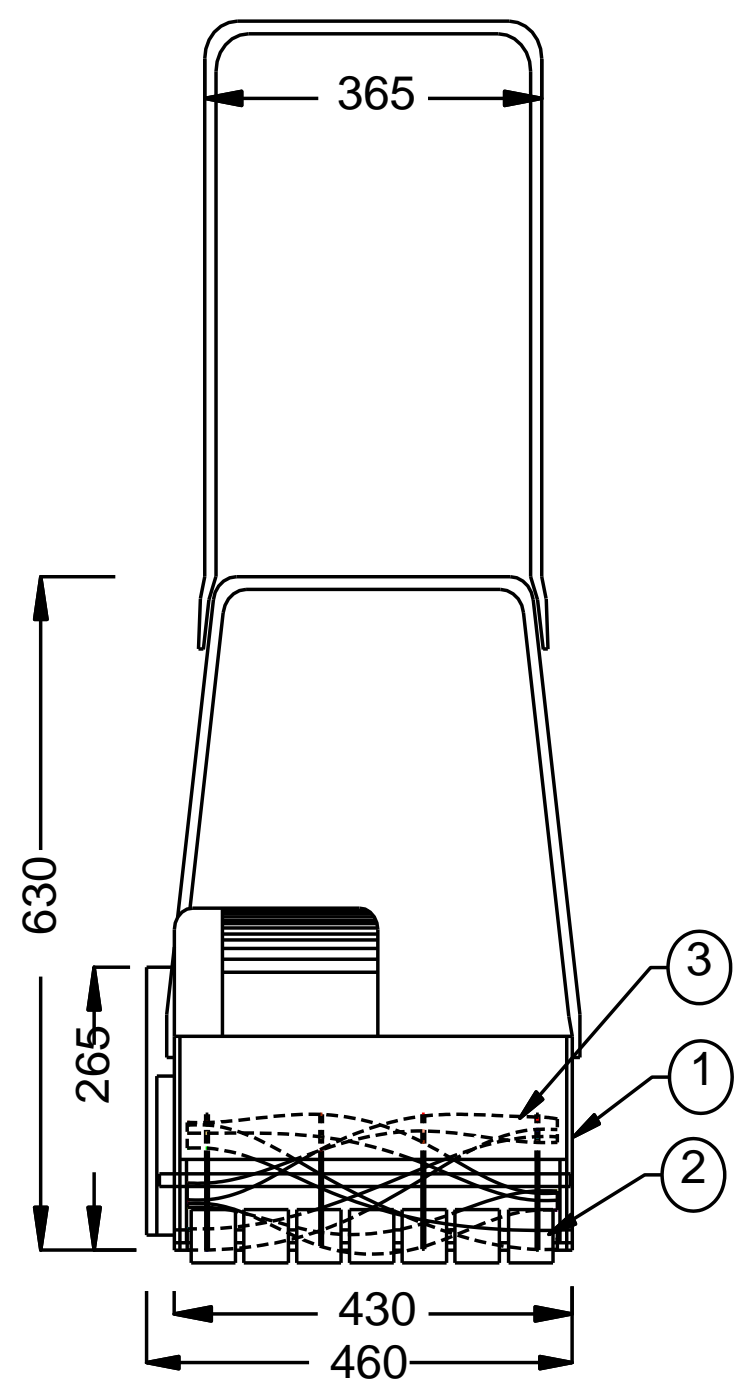

Elevation

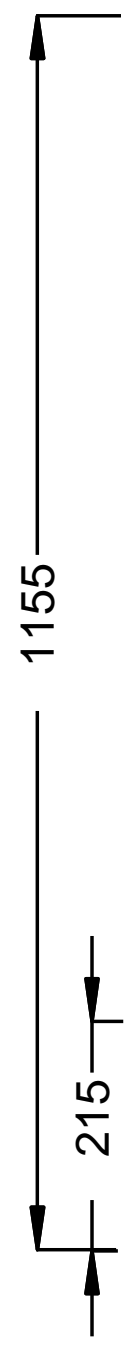

Dims.in mm

1-Frame 2 - Gauge rollers 3- Knives 4- Pressing drum 5- Electrical motor 6- Pushing handle

Fig. 1: The views grass and main parts of cutting machine. 


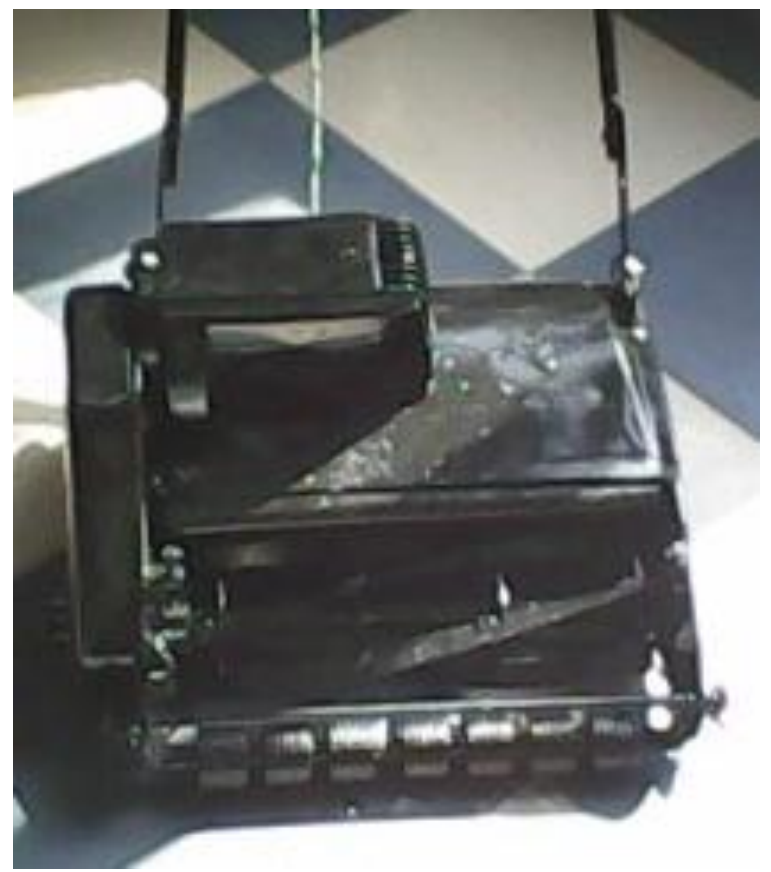

(a) Front view

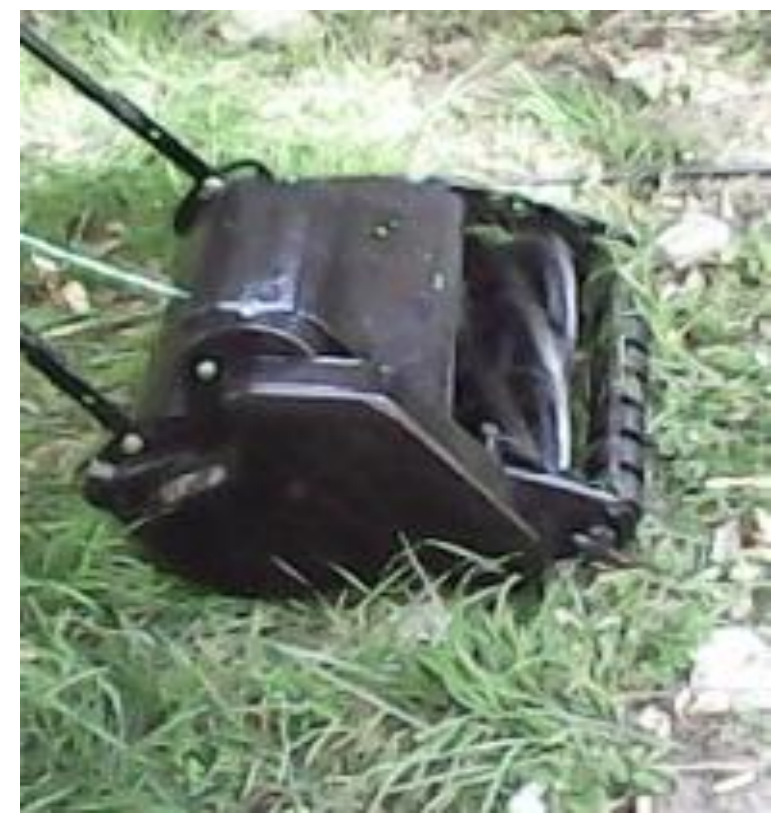

(b) Side view

Fig. 2: Photographs of developed grass-mower. 
width of $400 \mathrm{~mm}$, greatest height of $1155 \mathrm{~mm}$ and weighs of $31 \mathrm{~kg}$. The developed grass-mower consists of the following parts:

(a) Frame: frame made of steel metal with thickness of $3 \mathrm{~mm}$ with total diminutions of $115.5 \times 36.5 \mathrm{~cm}$.

(b) Cutting mechanism : cutting mechanism consists of cutting drum with 4 knives was run on the grass cutting-drum and fixed knife. Cutting drum had diameter of $13 \mathrm{~cm}$ and length of $43 \mathrm{~cm}$.

- Grass cutting-drum (Fig. 3): grass cutting-drum consists of 4 flanges and 4 knives with $400 \mathrm{~mm}$ length, $18 \mathrm{~mm}$ width $3 \mathrm{~mm}$ thickness.

-The knives (Fig 4, a and b): were curved with drum externally sharpened edges fixed at an angle of $30^{\circ}$ to the horizontal axis (flail type), The carbon steel knives were heat treated (hardened and tempered) for longer service life, number of knives on drum 4 knives for superior cutting and ease of pushing and one fixed knife, clearances between it less than a millimeter. This reduces friction and allows the mower to cut the grass like scissors.

(c) Drive drum: drive drum has diameter of $20 \mathrm{~cm}$ and length $43 \mathrm{~cm}$.

(d) Gauge rollers: gauge rollers number is 7 with diameter of $3.7 \mathrm{~cm}$. The gauge rollers used to adjust the cutting height by moving them using two sluts at two sides of the machine.

(e) Electrical motor and power transmission: electric motor of $1 \mathrm{hp}$ $(0.75 \mathrm{~kW})$ at 1400-2000 rpm and 4 wheels, 4 gears, sprockets and belts. The transmission system details were shown in Fig. 5 and 6.

(f) Handle: handle made of pipes with outside diameter of $6 \mathrm{~mm}$. The total dimensions of handle are height of $115.5 \mathrm{~cm}$ and $36.5 \mathrm{~cm}$ width. 

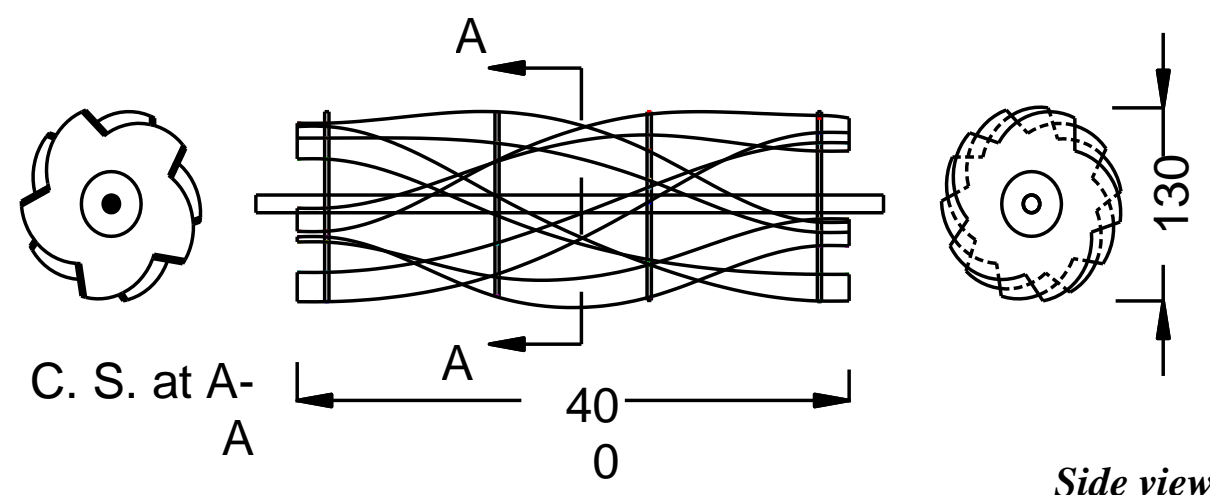

Side view

Dims..in $\mathrm{mm}$

Fig. 3: Views of grass cutting-drum.

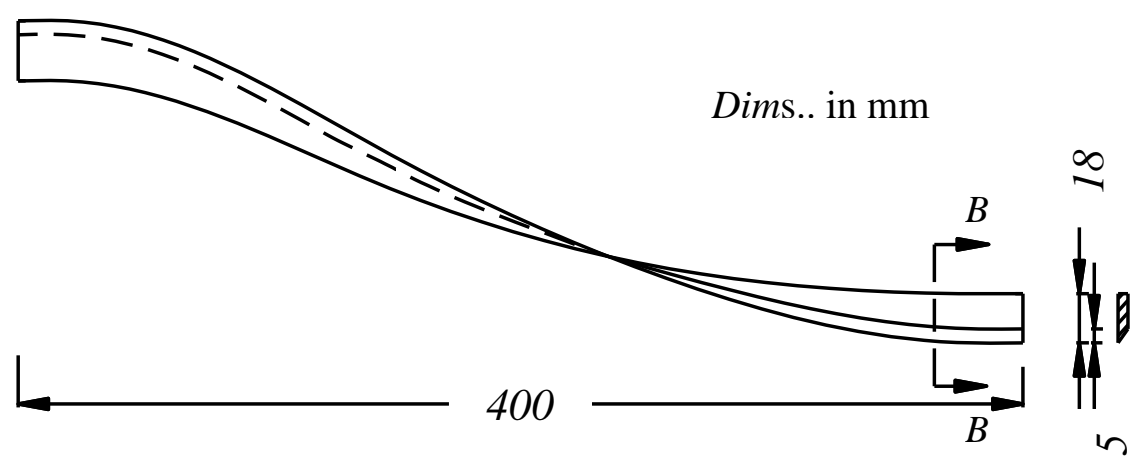

(a) Rotated knife.

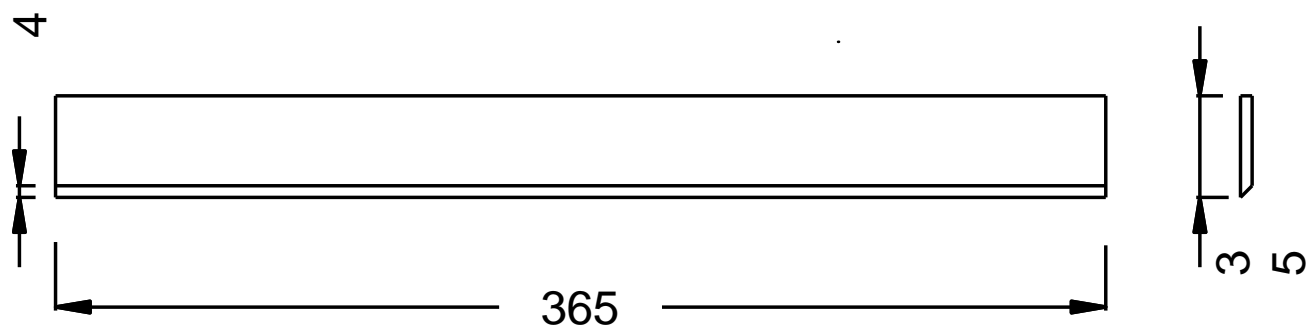

(b) Fixed knife.

Dims..in mm

Fig. 4: Views of cutting knives. 


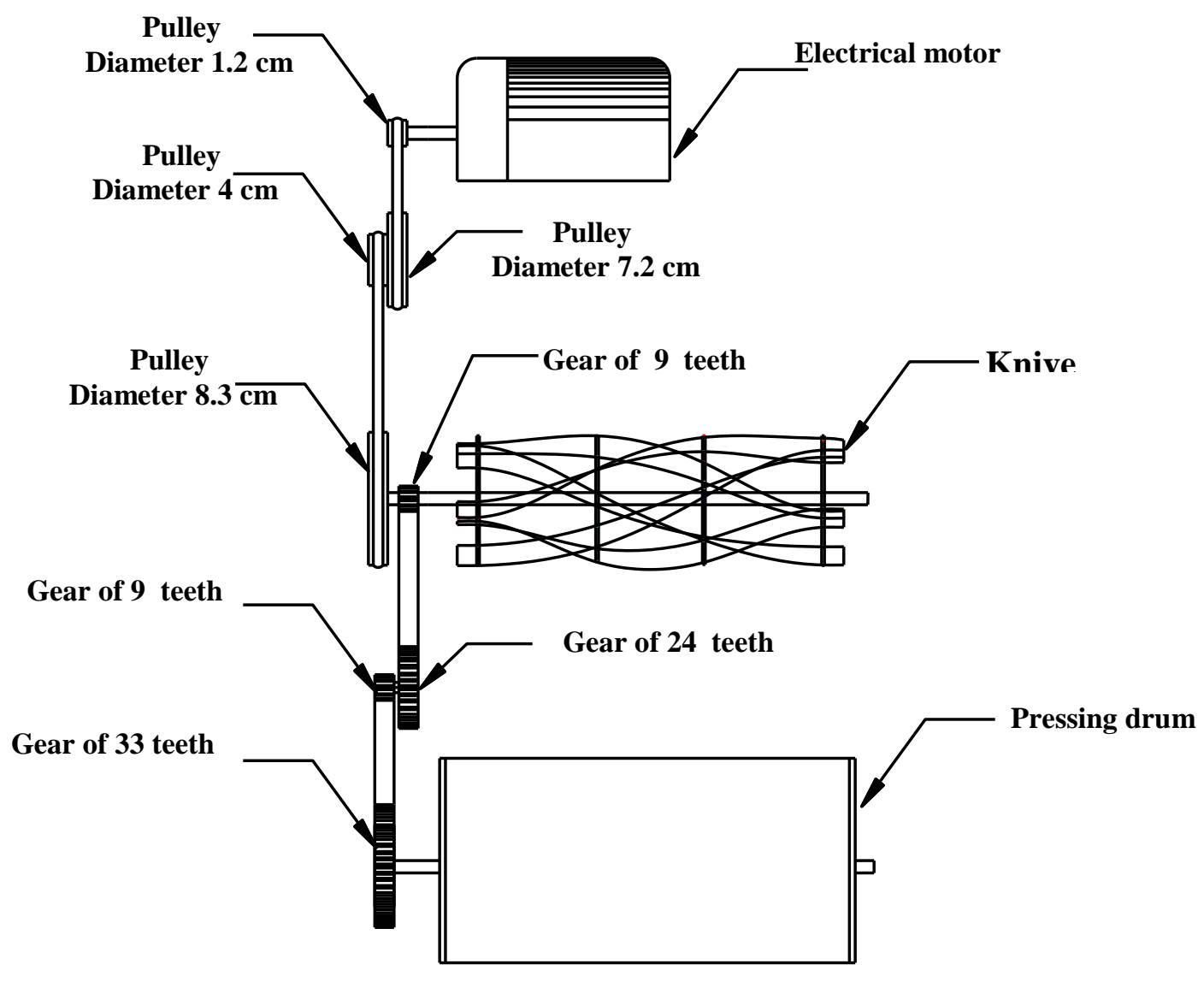

Fig. 5 : Transmission system

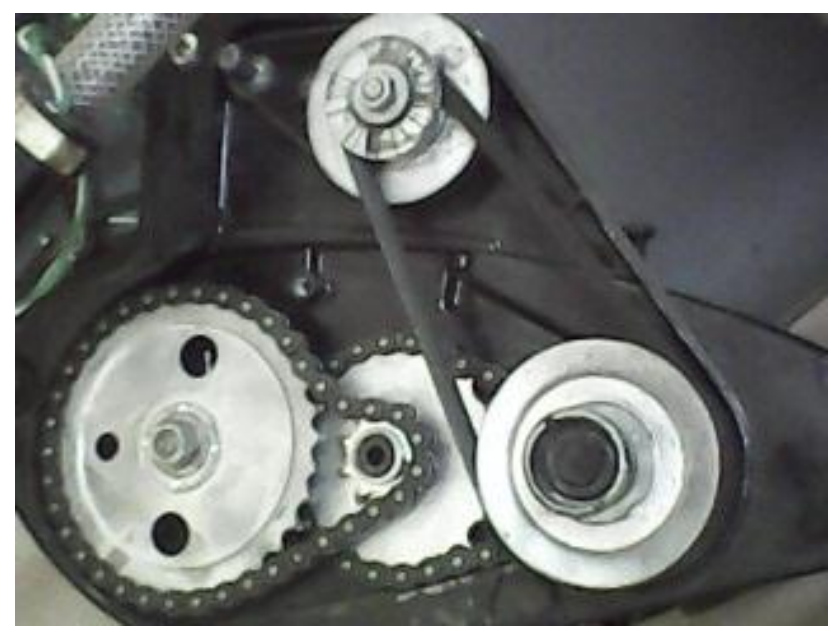

Fig. 6 : Photograph of transmission system 
Some physical properties of grass : Three different varieties of grass (Tefwaw, C-shore and Passplem) were randomly collected and chosen to determine the grass length, average weight, specific density and number of plants in one squire meter of the field. Each sample was 100 grass. Your mowing will vary greatly based upon the turf grass species, time of year and rainfall, but a typical frequency is one to two times per week during the growing season.

Some physical properties were studied and recorded as shown in Table 1 , average weight of mower grass in the deferent months as shown in Fig. 7.

Table 1: Some physical properties of the grass.

\begin{tabular}{|c|c|c|c|c|}
\hline $\begin{array}{c}\text { Varieties of } \\
\text { grass }\end{array}$ & $\begin{array}{l}\text { Average } \\
\text { length, } \\
\text { cm. }\end{array}$ & $\begin{array}{c}\text { Number of } \\
\text { grass } / \mathrm{m}^{2}\end{array}$ & $\begin{array}{l}\text { Average number of } \\
\text { grass cutting, month }\end{array}$ & $\begin{array}{c}\text { Average weight of } \\
\text { grass cutting, } \\
\mathrm{kg} / \mathrm{m}^{2}\end{array}$ \\
\hline Tefway & \multirow{3}{*}{$15: 20$} & \multirow{3}{*}{1500} & \multirow{3}{*}{$2: 4$} & \multirow{3}{*}{3.5} \\
\hline C-shore & & & & \\
\hline Passplem & & & & \\
\hline
\end{tabular}

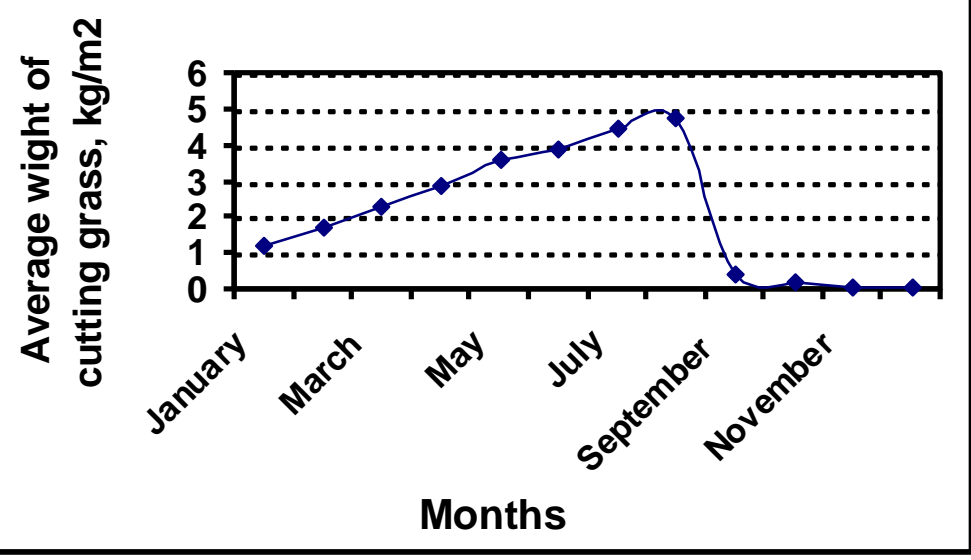

Fig 7: Average weight of cutting grass in the deferent months.

The tested factors: The tested factors were:

(1) Cutting speed: the tested cutting-speeds were 4.1, 4.7, 5.3 and $6 \mathrm{~m} / \mathrm{s}$.

(2) Cutting height: the tested cutting-heights were 2, 3, 4 and $5 \mathrm{~cm}$ 
(3) Forward speed : the tested forward-speeds were 0.84, 1.33, 1.76 and $2.16 \mathrm{~km} / \mathrm{h}$.

\section{Measurements :}

(1) Performance rate, (2) Cutting efficiency,

(3) Power and specific energy.

\section{Equations and calculations :}

Cutting efficiency: cutting efficiency was calculated by measuring the stem length before cutting and the length of residual after cutting. The cutting efficiency was calculated according to the following equation:

Cutting efficiency $(\eta \%)=(\mathrm{Lb}-\mathrm{La}) / \mathrm{Lb}$

$\mathrm{Lb}=$ Length before cutting.

La $\quad=$ Residual length after cutting.

The length of the residual before and after cutting was measured as average from 100 random samples which were collected from before cutting and from residues after cutting.

Specific energy: It was calculated by using the following equation:

$$
\mathrm{E}=\mathrm{P} / \mathrm{M}
$$

Where:-

$\mathrm{E}=$ specific energy $\mathrm{kW} . \mathrm{h} / \mathrm{fed}$.,

$\mathrm{P}=$ total power, $\mathrm{kW}$,

$\mathrm{M}=$ productivity fed./h.

Estimating the costs of using the machines: Cost of operation was calculated according to the equation given by Awady (1978), in the following form:

$$
\mathrm{C}=\mathrm{p} / \mathrm{h}(1 / \mathrm{a}+\mathrm{i}+\mathrm{t} / 2+\mathrm{r})+(\mathrm{Ec} * \mathrm{Ep})+\mathrm{m} / 144,
$$

Where:

$\mathrm{C}=$ hourly cost, L.E./h ; $\quad \mathrm{p}=$ price of machine, L.E;

$\mathrm{h}=$ yearly working hours, $\mathrm{h}$;

$\mathrm{a}=$ life expectancy of the machine, year ;

$\mathrm{i}=$ interest rate/year ; $\quad \mathrm{t}=$ taxes ;

$\mathrm{r}=$ overheads and indirect cost ratio ;

$\mathrm{Ec}=$ Electricity consumption $\mathrm{kW} \cdot \mathrm{h} / \mathrm{h}$;

Ep = Electricity price L.E/kW.h, "144" are estimated monthly working hours. Notice that all units have to be consistent to result in L.E/h. 


\section{RESULTS AND DISCUSSION}

\section{Effect of forward speed, cutting speed and cutting height on machine productivity.}

Fig. 8 shows the effect of forward speed, cutting speed and cutting height on machine productivity.

The maximum machine productivity of $599.4 \mathrm{~m}^{2} / \mathrm{h}(0.143 \mathrm{fed} . / \mathrm{h})$ was obtained with forward speed $2.16 \mathrm{~km} / \mathrm{h}$, cutting height of $2 \mathrm{~cm}$ and cutting speed of $6 \mathrm{~m} / \mathrm{s}$.. Meanwhile, the minimum machine productivity of 216.9 $\mathrm{m}^{2} / \mathrm{h}(0.052 \mathrm{fed} . / \mathrm{h})$ was obtained with forward speed of $0.84 \mathrm{~km} / \mathrm{h}$, cutting height of $5 \mathrm{~cm}$ and cutting speed of $4.1 \mathrm{~m} / \mathrm{s}$.

Results show a consequent grass cutting in productivity as the forward speed increased under all conditions. Results show that the productivity increased by increasing cutting speed. This trend can be explained as follows: at high cutting height, the knife cannot be able to cut grass successfully because of high cutting resistance which is due to shear.
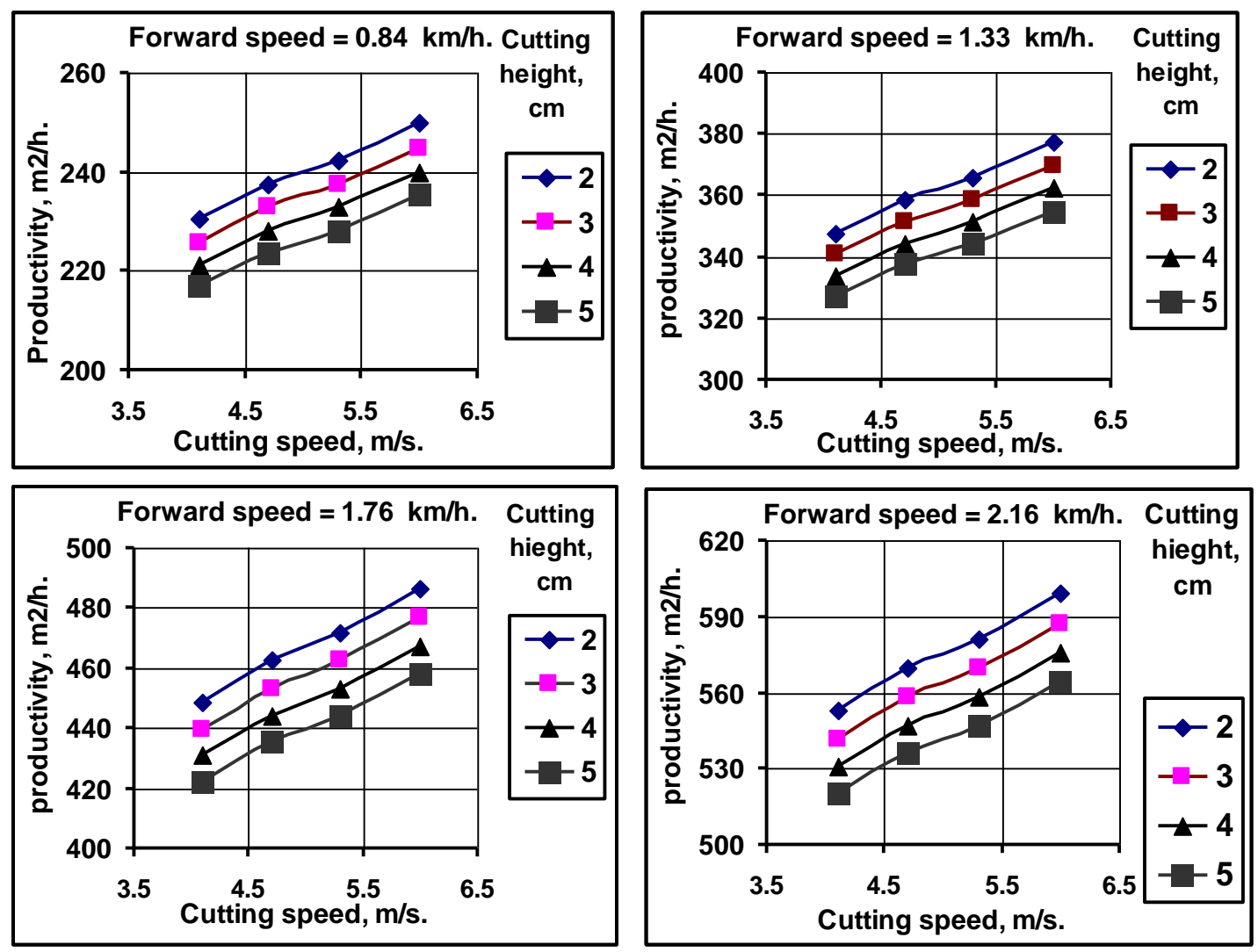

Fig 8: Effect of forward speed, cutting speed and cutting height on machine productivity. 


\section{Effect of forward speed, cutting speed and cutting height on cutting efficiency.}

Fig. 9 shows the effect of the forward speed, cutting speed and cutting height on cutting efficiency.

The maximum value of cutting efficiency ( $98.8 \%$ ) was obtained with forward speed $0.84 \mathrm{~km} / \mathrm{h}$, cutting height of $2 \mathrm{~cm}$ and cutting speed, $6 \mathrm{~m} / \mathrm{s}$. Meanwhile, the minimum value of cutting efficiency of $(26.0 \%)$ was obtained with forward speed of $2.16 \mathrm{~km} / \mathrm{h}$, cutting height of $5 \mathrm{~cm}$ and cutting speed, $4.1 \mathrm{~m} / \mathrm{s}$.

Higher values of forward speed more than $2.0 \mathrm{~km} / \mathrm{h}$ were more effective in increasing productivity but tended to increase grass losses which in turn decreased cutting efficiency because of the high impact of the machine with the grass. Low values of forward speed less than $1.33 \mathrm{~km} / \mathrm{h}$ also decreased cutting efficiency because of the excessive number of knife impact per unit time on the grass, resulting in serious damage.
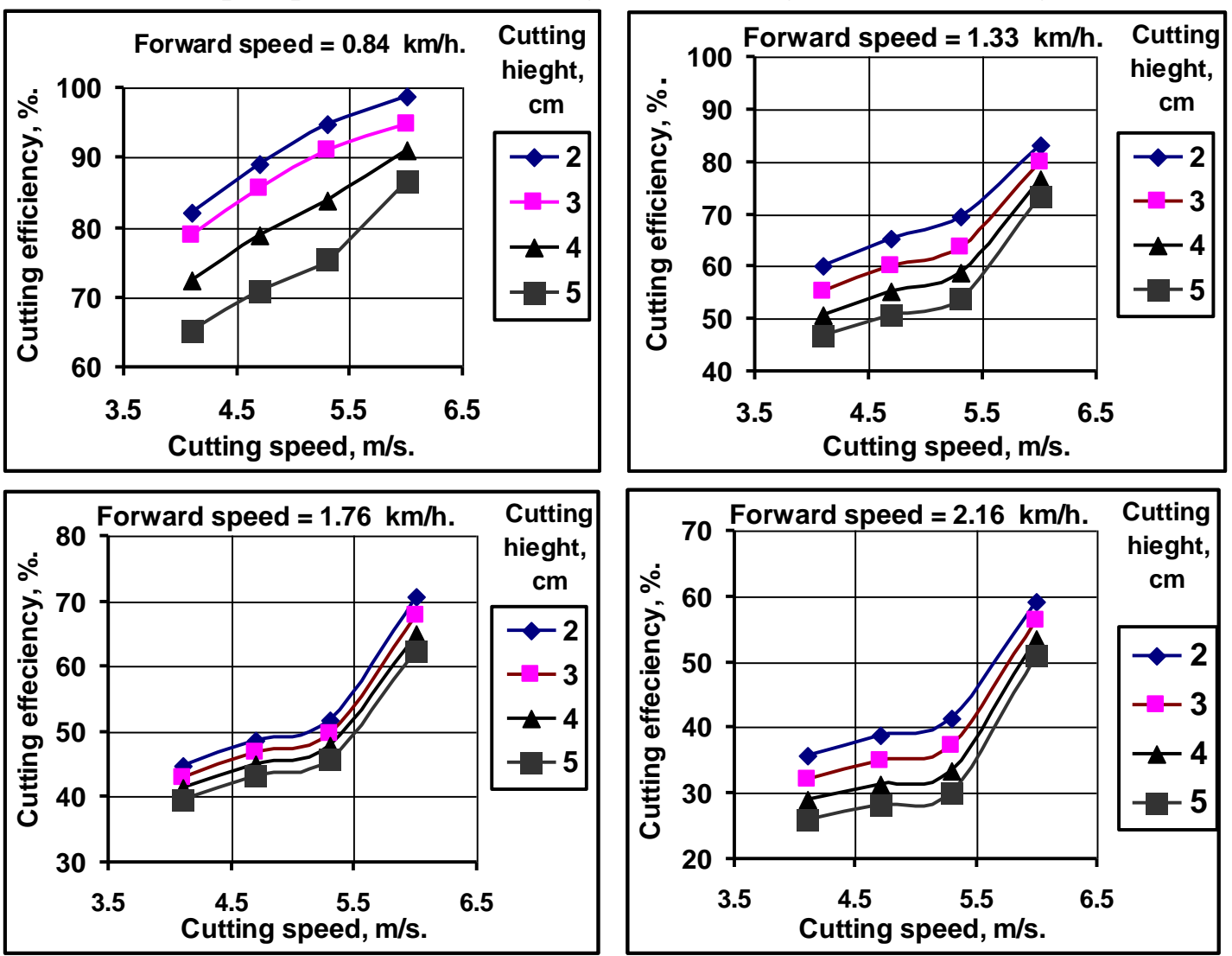

Fig 9 : Effect of forward speed, cutting speed and cutting height on cutting efficiency. 


\section{Effect of forward speed, cutting speed and cutting height on power} requirements.

Fig. 10 shows the effect of forward speed, cutting speed and cutting height on power requirements.

The maximum power requirement of $0.70 \mathrm{~kW}$ was obtained with forward speed $2.16 \mathrm{~km} / \mathrm{h}$, cutting height of $5 \mathrm{~cm}$ and cutting speed, $6 \mathrm{~m} / \mathrm{s}$. Meanwhile, the minimum power requirement of $0.39 \mathrm{~kW}$ was obtained with forward speed $0.84 \mathrm{~km} / \mathrm{h}$, cutting height of $2 \mathrm{~cm}$ and cutting speed, $4.1 \mathrm{~m} / \mathrm{s}$. The increase in power required by increasing forward speed is attributed to the excessive material in front of the machine .
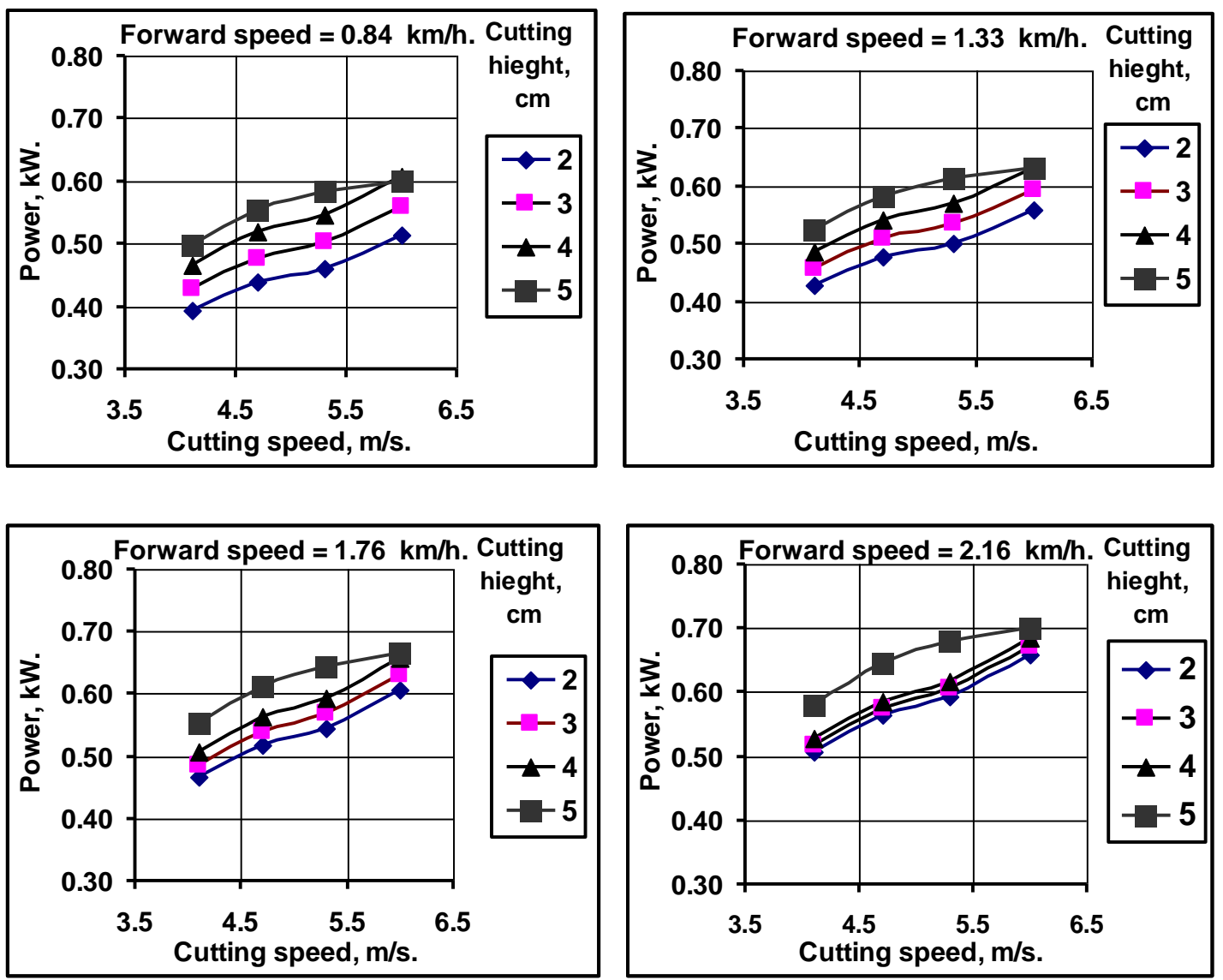

Fig 10 : Effect of forward speed, cutting speed and cutting height on power. 
Effect of forward speed, cutting speed and cutting height on specific energy.

Fig. 11 shows the effect of forward speed, cutting speed and cutting height on specific energy.

The maximum value of specific energy $(11.27 \mathrm{~kW} . \mathrm{h} / \mathrm{fed}$.) was obtained with forward speed $0.84 \mathrm{~km} / \mathrm{h}$, cutting height of $5 \mathrm{~cm}$ and cutting speed of $6 \mathrm{~m} / \mathrm{s}$. Meanwhile, the minimum value of specific energy $(3.55$ $\mathrm{kW} . \mathrm{h} / \mathrm{fed}$.) was obtained with forward speed of $2.16 \mathrm{~km} / \mathrm{h}$, cutting height of $2 \mathrm{~cm}$ and cutting speed of $4.1 \mathrm{~m} / \mathrm{s}$.

The decrease of energy requirements by increasing forward speed is due to the increase of machine field capacity. Regarding the influence of knife speed on both power and energy requirements, results show that power and energy are affected by the forward speed and cutting speed resulting in a sharp increase in the required power with a decrease in energy requirements.

\section{Costs of using the developed grass-mower.}

Table 2 shows the components of the Awady equation. The operation and production costs at optimum conditions (forward speed of $0.84 \mathrm{~km} / \mathrm{h}$, cutting speed of $6 \mathrm{~m} / \mathrm{s}$ and cutting height of $2 \mathrm{~cm}$ ) were 11.5 L.E./h. and 193.3 L.E./fed.

Table 2: The components of Awady equation.

\begin{tabular}{|c|c|c|c|c|c|c|c|c|}
\hline $\begin{array}{c}\mathrm{p}, \\
\text { L.E. }\end{array}$ & $\mathrm{h}, \mathrm{h}$ & $\begin{array}{c}\mathrm{a}, \\
\text { year }\end{array}$ & $\mathrm{i}$ & $\mathrm{t}$ & $\mathrm{r}$ & $\begin{array}{c}\mathrm{Ec}, \\
\mathrm{kW} . \mathrm{h} / \mathrm{h}\end{array}$ & $\begin{array}{c}\mathrm{Ep}, \\
\text { L.E. }\end{array}$ & $\begin{array}{c}\mathrm{m}, \\
\text { L.E }\end{array}$ \\
\hline 3000 & 1000 & 10 & 0.075 & 0.05 & 0.03 & 1.2 & 0.25 & 1500 \\
\hline
\end{tabular}

$\mathrm{C}=(3000 / 1000) *(0.1+0.075+0.05+0.03)+(1.2 * 0.25)+1500 / 144=11.5 \mathrm{LE} / \mathrm{h}$.

\section{Operational cost and cost of production.}

Regarding the effect of forward speed on criterion cost results show that by decreasing forward speed criterion cost decreased up to 0.84 ; any further increase in for ward speed up to $2.16 \mathrm{~km} / \mathrm{h}$, criterion cost will increased.

Table 3 shows the operational cost and cost of production optimum forward speed of $0.84 \mathrm{~km} / \mathrm{h}$ and cutting speed of $6 \mathrm{~m} / \mathrm{s}$, and different cutting height $(2,3,4,5$ and $6 \mathrm{~cm})$ were cost of production (193.3, 197.2, 201.2 and 205.4 L.E./fed.) respectively. 

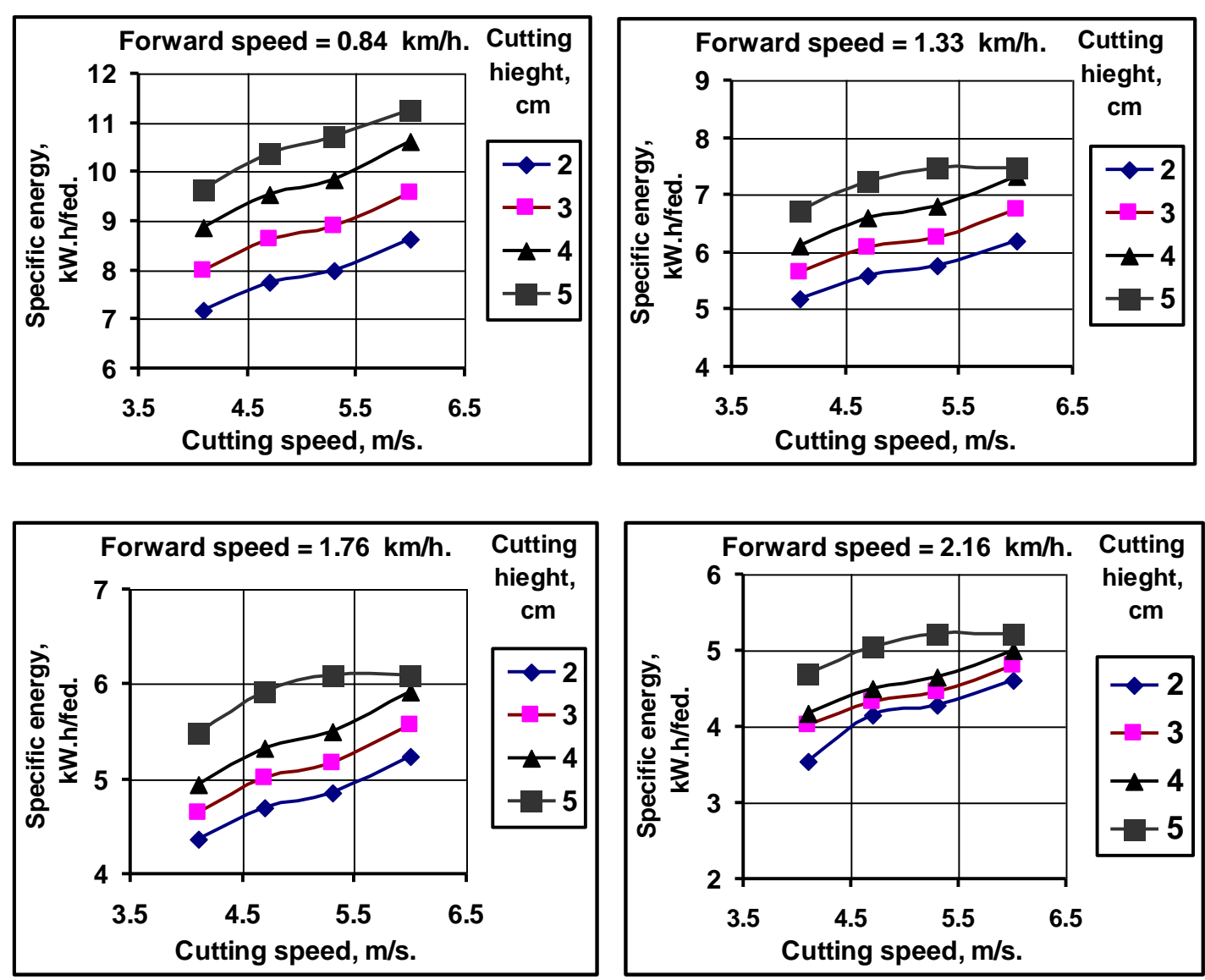

Fig 11 : Effect of forward speed, cutting speed and cutting height on specific energy..

Table 3: Operational cost and cost of production.

\begin{tabular}{|c|c|c|c|c|}
\hline $\begin{array}{c}\text { Cutting } \\
\text { height, } \\
\text { cm } \\
\end{array}$ & $\begin{array}{l}\text { Operational } \\
\text { cost, L.E./h }\end{array}$ & $\begin{array}{c}\text { Production, } \\
\text { Fed./h } \\
\end{array}$ & $\begin{array}{c}\begin{array}{c}\text { Cost of } \\
\text { production, }\end{array} \\
\text { L.E./fed. }\end{array}$ & $\begin{array}{c}\text { Cutting } \\
\text { efficiency, } \\
\%\end{array}$ \\
\hline 2 & \multirow{4}{*}{11.5} & 0.060 & 193.3 & 98.8 \\
\hline 3 & & 0.058 & 197.2 & 94.9 \\
\hline 4 & & 0.057 & 201.2 & 91.1 \\
\hline 5 & & 0.056 & 205.4 & 86.5 \\
\hline
\end{tabular}




\section{CONCLUSION}

The optimum conditions of using the developed grass-mower were: forward speed of $0.84 \mathrm{~km} / \mathrm{h}$, cutting speed of $6 \mathrm{~m} / \mathrm{s}$ and cutting height of $2 \mathrm{~cm}$. The obtained results at optimum conditions were: machine productivity of $0.06 \mathrm{fed} / \mathrm{h}\left(250 \mathrm{~m}^{2} / \mathrm{h}\right)$, cutting efficiency of $98.8 \%$, power of $0.51 \mathrm{~kW}$, specific energy of $8.62 \mathrm{~kW} . \mathrm{h} / \mathrm{fed}$. and operational cost and cost of production of 11.5 L.E./h and 193.3 L.E./fed. respectively.

\section{REFFERENCES}

Awady, M. N., 1978, Tractors and farm machines, in Arabic, text. Col. Ag., A. Shams U.: 164-167.

Celik, A., 2006, Design and operating characteristics of a push type cutter bar mower, Canadian Biosystems Engineering, 48: 23-27.

Chattopadhyay, P. S.; Ranabir M. and Mahapatra, M., 2010, Performance evaluation of different machines on harvesting baffle grass. Journal of Interacademicia, 14: 186-190.

Jagielski, K. and Treder, W., 1998, Operating tests on orchard mowers, Zeszyty Naukowe Instytutu Sadownictwa Kwiaciarstwa Skierniewicach; 5: 65-81

Keepin, M. 2003, Look sharp. Leisure Manager. 21: 14-15.

Kemper, S.; Lang, T. and Frerichs, L., 2012, Analysis of the overlaying cut in rotary mowers. Landtechnik;67: 346-349.

Kumhala, F., 1998, Comparison of mowing machines used by agricultural machinery for small scale arming. Scientia Agriculturae Bohemica; 29: 259-267.

Kumhala, F.; Kroulik, M.; Masek, J.; Prosek, V. 2003, Development and testing of two methods for the measurement of the mowing machine feed rate. Plant, Soil and Environment; 2003. 49: 11, 519-524. 8 ref.

Magar, A. P.; Abuj, M. D.; Bastewad, T. B.; Adagale, P. V. 2010, Performance evaluation of grass cutter. International Journal of Agricultural Engineering; 2010. 3: 1, 153-155. 1 ref. 
Piccarolo, P. 2012, Cutting grass: lawns and sports surfaces. Mondo Macchina; 2012. 21: 3/4, 52-55.

\section{الملخص العزبي \\ تطوير آلة لحش النجيل}

*ـ. ميرفت محمد عطالله

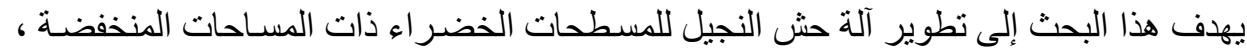

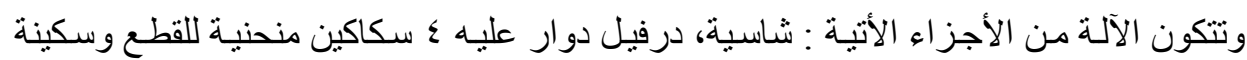

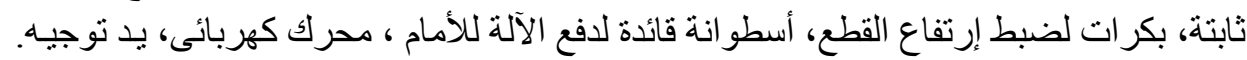

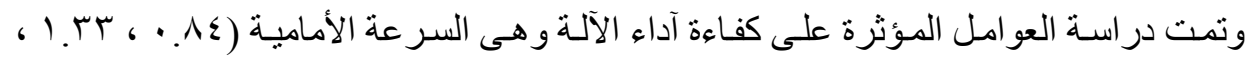

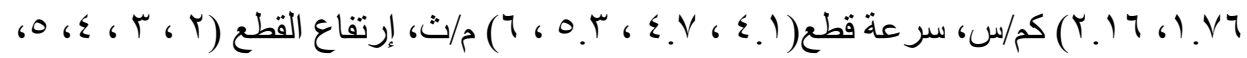
T) سم، وكان ملخص النتائج كالتالى : (17 (1)

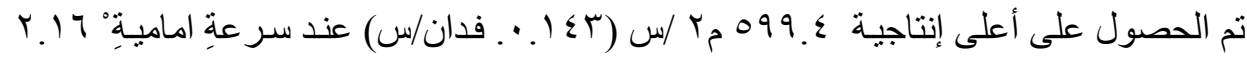

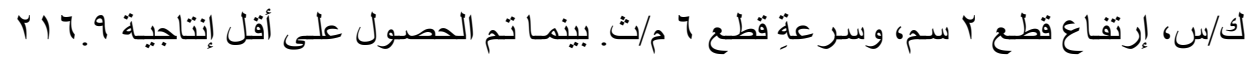

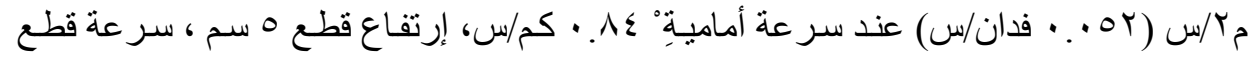
.

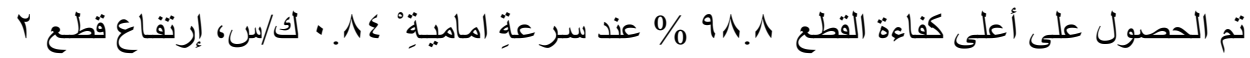

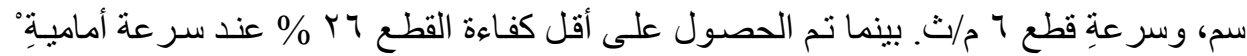

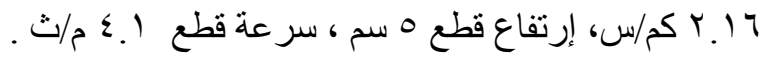

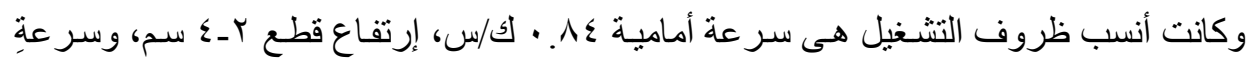
قطع 7 م/ثات.

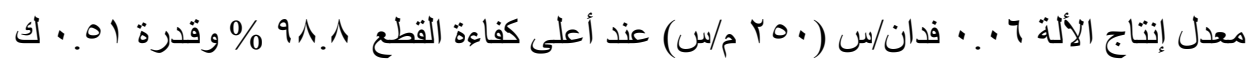

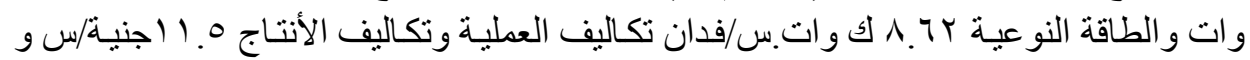
r. آوا جنية /فدان على الترتيب. 